\title{
Surgery in ulcerative colitis - Return of the ileorectal anastomosis
}

\author{
CARL-ERIC LeIJONMARCK, MD, GÖRAN Hellers, MD
}

\begin{abstract}
The main advantages of ileorectal anastomosis for patients with ulcerative colitis are that it is easier to perform and the complication rate is probably lower than for the pelvic pouch procedure. Ileorectal anastomosis is, however, not suitable for all patients. Patients with severely inflamed and scarred rectums with low compliance are not suitable candidates for the procedure. With the use of the new steroids, however, the number of patients suitable for ileorectal anastomosis will probably increase. The functional outcome, particularly in terms of continence, is probably better following ileorectal anastomosis than after pelvic pouch. The need for long term cancer surveillance is a problem, but newer methods for surveillance may increase further the possibilities of controlling cancer risk in the future. There seems to be an equal need for future medical surveillance following both surgical procedures. In balance, newer methods of medical therapy and cancer surveillance will probably lead to a return to ileorectal anastomosis in a significant number of patients. Can J Gastroenterol 1990;4(7):439-442 (pour résumé, voir page 440)
\end{abstract}

Key Words: Colectomy, Ileorectal anastomosis, Pelvic pouch, Surgery, Ulcerative colitis

Department of Surgery, St Görans and Huddinge Hospital, Stockholm, Sweden

Correspondence and reprints: Dr Carl-Eric Leijonmarck, Department of Surgery, St Görans Hospital, S-11281 Stockholm, Sweden. Telephone 046-8-130500

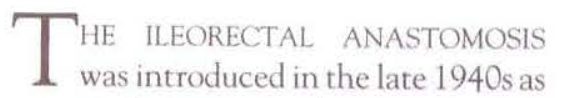
a surgical alternative for patients with ulcerative colitis. Aylett (1) became the leading proponent of the procedure during the $1950 \mathrm{~s}$ and ' $60 \mathrm{~s}$. The main advantages are that the procedure is technically fairly simple, can be performed in one stage and has a low complication rate. The main disadvantages are the risk of recurrent inflammmation of the rectum, cancer risk and the need for ongoing surveillance.

In later years the ileorectal anastomosis has been less used, probably because of the introduction of the mucosal proctectomy with pelvic pouch and ileoanal anastomosis (pelvic pouch) (2). The introduction of this method is probably responsible for an increase in the colectomy rate in 


\section{La chirurgie et la colite ulcéreuse: Retour à l'anastomose iléo-rectale}

RESUME: Les avantages principaux de l'anastomose iléo-rectale chez les patients atteints de colite ulcéreuse est qu'elle est plus facile que l'institution d'une poche pelvienne et que son taux de complications est probablement quelque peu inférieur. L'anastomose iléo-rectale ne convient cependant pas à tous les patients. Elle n'est pas indiquée dans le cas des personnes dont le rectum est sévèrement inflammé et lésé et qui se plient difficilement aux traitements. Pourtant, la mise au point de nouveaux stéroïdes provoquera probablement une augmentation des candidats à cette intervention. Le résultat fonctionnel, en terme de continence surtout, est probablement meilleur après une anastomose iléo-rectale qu'après une poche pelvienne. La nécessité des examens de surveillance à long terme est un problème, mais de nouvelles méthodes pourraient là aussi améliorer le contrôle des risques du cancer à l'avenir. La surveillance médicale est nécessaire à la suite des deux types d'intervention chirurgicale. En conclusion, les nouveaux traitements médicaux et modes de dépistage du cancer entraîneront probablement le retour à l'anastomose iléo-rectale chez un nombre important de patients.
Stockholm County during the past years (3).

Surgical preferences vary over time - a good example of this is peptic ulcer surgery. Surgeons tend to discuss the choice of method independent of the medical background. Radical changes in medical therapy may substantially change the prerequisites for choice of surgical method.

It is likely that there will be major changes in the medical therapy of ulcerative colitis. Recently, a number of new potent steroids have been introduced. These have predominantly local effects and can be used without suppressing endogenous steroid production. In principle there are two types of new steroids - they are either absorbed and rapidly degraded in first liver passage or not absorbed at all. Theoretically the first type should be more effective in Crohn's disease since this is a transmural inflammation, and the second type should be more suitable for ulcerative colitis. In the case of rectal ulcerative colitis the first type of steroid could also be useful since it should prevent rectal scarring and keep the rectum compliant even in patients with longstanding ulcerative colitis. It is likely that the absence of side effects will allow these steroids to be used in higher doses and for longer periods of

In a recent Swedish multicentre trial one of the new steroids - budesonide time in the future. was compared with prednisolone disodium phosphate enema in patients with active distal ulcerative colitis (4). The study included 64 patients, of which 31 received budesonide and 33 prednisolone as a retention enema. Budesonide was found to be superior to prednisolone in terms of significantly improved sigmoidoscopic and histological scores, as well as for symptoms.

With this background of changing medical therapy it is interesting to compare the ileorectal anastomosis and the pelvic pouch. These two methods can be compared on the following factors: technical feasibility, factors affecting long term outcome, functional outcome, long term cancer risk and need for continued medical treatment and/or surveillance.

Technical feasibility: The complication rates following ileorectal anastomosis from recent studies from Stockholm (5) and the Cleveland
TABLE 1

Postoperative complications in patients with ulcerative colitis treated by ileorectal anastomosis

\begin{tabular}{lcc}
\hline & $\begin{array}{c}\text { Stockholm } \\
(5)(n=51)\end{array}$ & $\begin{array}{c}\text { Cleveland } \\
(6)(n=145)\end{array}$ \\
\hline Leaks & $4.7 \%$ & $2.1 \%$ \\
Abscesses & $2.3 \%$ & $3.4 \%$ \\
SBO & $2.3 \%$ & $2.1 \%$ \\
Other & $4.7 \%$ & $2.6 \%$ \\
All & $14.0 \%$ & $10.2 \%$ \\
\hline SBO Small & bowel obstruction requiring \\
laparotomy & \multicolumn{2}{c}{}
\end{tabular}

Clinic (6) are fairly low (Table 1). The postoperative complications following pouch surgery in some recently publish. ed series are shown in Table 2 (7-9). The complication rate is somewhat higher than following ileorectal anastomosis.

Factors affecting long term outcome: Attempts have been made to establish possible predictors for selecting patients with ulcerative colitis for ileorectal anastomosis, but the recommendations in the literature are conflicting. In the study from Stockholm concerning 51 patients with ileorectal anastomosis the only factor of importance for outcome was the preoperative presence of mild rectal disease (5). Sixty-seven per cent of patients with preoperative mild rectal disease still had a functional ileorec. tal anastomosis 10 years after surgery (5). The method seemed to have a good prognosis if the inflammation in the rectum could be controlled.

Functional outcome: The functional outcome of the pelvic pouch has been reported from several centres. The outcome may be affected by the pouch type, the final pouch size and the level of the ileoanal anastomosis. In a review

\section{TABLE 2}

Postoperative complications in patients with ulcerative colitis treated by pelvic pouch

\begin{tabular}{lccc}
\hline & $\begin{array}{c}\text { Toronto (7) } \\
(n=179)\end{array}$ & $\begin{array}{c}\text { Mayo (8) } \\
(n=390)\end{array}$ & $\begin{array}{c}\text { Minneapolis (9) } \\
(n=178)\end{array}$ \\
\hline Pelvic sepsis/ & $10 \%$ & $5 \%$ & $5 \%$ \\
anastomotic leakage & $10 \%$ & $5 \%$ & $3 \%$ \\
Small bowel obstruction & $7 \%$ & $10 \%$ & $12 \%$ \\
Other major & $27 \%$ & $20 \%$ & $20 \%$ \\
All & & & \\
\hline
\end{tabular}

"Requiring laparotomy 
TABLE 3

Comparison of functional outcome in patients with ileorectal anastomosis (IRA) or pelvic pouch (PP)

\begin{tabular}{lccccc}
\hline & \multicolumn{2}{c}{ Bowel movements } & \multicolumn{2}{c}{ Continence } & Antidiarrheal \\
& Mean & Nocturnal & Daytime & At night & medication \\
\hline IRA $(5,6)$ & 4 & $2 \%$ & $100 \%$ & $100 \%$ & $24 \%$ \\
PP $(8,11,12)$ & 6 & $36 \%$ & $87 \%$ & $78 \%$ & $32 \%$ \\
\hline
\end{tabular}

TABLE 4

Long term cancer risk following ileorectal anastomosis

\begin{tabular}{|c|c|c|c|}
\hline & $\begin{array}{c}\text { Number of } \\
\text { cases }\end{array}$ & $\begin{array}{c}\text { Number of } \\
\text { cancers }\end{array}$ & Cumulative cancer risk \\
\hline Gordons Hospital (13) & 374 & 6 & $\begin{array}{l}6 \% \text { at } 20 \text { years } \\
15 \% \text { at } 30 \text { years }\end{array}$ \\
\hline Alfred Hospital (14) & 155 & 6 & $17 \%$ at 27 years \\
\hline St Marks Hospital (15) & 125 & 4 & Not stated \\
\hline Cleveland Clinic (16) & 109 & 5 & Not stated \\
\hline Mayo Clinic (17) & 63 & 0 & 0 \\
\hline Stockholm County (5) & 51 & 0 & 0 \\
\hline
\end{tabular}

by Nicholls in $1987(10)$ there seemed to be no major difference between different types of pouches.

In an attempt to compare functional outcome, the results of ileorectal anastomosis in Stockholm (5) and the Cleveland Clinic (6) were compared with the outcome of pelvic pouch procedures from Stockholm (11), Minneapolis (12) and the Mayo Clinic (8) (Table 3 ). The comparison shows that in these series the ileorectal anastomosis had better functional results than pelvic pouch, particularly in terms of continence.

Long term cancer risk: The main argument against ileorectal anastomosis has been the risk of rectal cancer. To determine the risk of cancer there are two main considerations: the series must be population-based and the follow-up must be long. The cancer risk in both hospital-based series and populationbased series are presented in Table 4 . The cumulative cancer risk has been reported to be about $10 \%$ at 25 years $(13,14)$. No patient developed carcinoma of the rectum in the series from Stockholm, but in three patients the rectum was excised due to development of dysplasia (5). No cancers were found in the series from the Mayo Clinic (17).

Recently newer methods for cancer surveillance have been developed, the most important of which is flow cytometric DNA analysis (18). This method has high reproducibility, is less sensitive to inflammation than conventional histology and, in a recent study by Löfberg et al (19), detected changes approximately two years earlier than conventional histology. A combination of flow cytometric DNA analysis and histology should increase the sensitivity of cancer surveillance.

In a study from Stockholm of mucosal dysplasia and DNA content in the rectal mucosa in 15 patients with a functional ileorectal anastomosis, there were no findings of dysplasia, carcinoma or DNA aneuploidy (unpublished observations). The risk of malignant transformation in patients with functional ileorectal anastomosis seems to be low and the new methods of cancer detection make it possible to detect precancerous changes at an earlier stage.

The new technique for the pelvic pouch procedure employs stapling the ileoanal anastomosis (20); therefore, anorectal mucosa is left behind with the risk of cancer development leading to the need for surveillance. The trend of leaving anorectal mucosa is a step towards ileorectal anastomosis.

Continued medical treatment/surveillance: Following ileorectal anastomosis there is a need for cancer surveillance and a need to treat recurrent inflamma- tion in the retained rectum. Pouchitis seems to emerge as a more important problem than initially conceived. In a prospective study in 100 patients the cumulative risk of pouchitis was $30 \%$ at two years (21).

\section{SUMMARY}

In summary, ileorectal anastomosis is easier to perform and the complication rate probably lower than for the pelvic pouch procedure. Ileorectal anastomosis is certainly not feasible for all ulcerative colitis patients. Patients with severely inflamed and scarred rectums with low compliance are not suitable candidates for the procedure. With the use of the new steroids, however, the number of suitable patients will probably increase in the future. The functional outcome, particularly in terms of continence, is probably better following ileorectal anastomosis than after the pelvic pouch procedure. The need for long term cancer surveillance is a problem, but newer methods of surveillance may further increase the possibility of controlling cancer. Final$1 y$, there seems to be an equal need for future medical surveillance following both methods.

\section{REFERENCES}

1. Aylett SO. Three hundred cases of diffuse ulcerative colitis treated by total colectomy and ileorectal anastomosis. Br Med J 1966;1:1001-5.

2. Parks AG, Nicholls RJ. Proctocolectomy without ileostomy for ulcerative colitis. Br Med J 1978;28:85-8.

3. Leijonmarck CE, Persson PG, Hellers G. Factors affecting colectomy rate in ulcerative colitis: An epidemiological study. Gut 1990;31:329-33.

4. Danielsson $\AA$, Hellers G, Lyrenäs E, et al. A controlled randomized trial of budesonide versus prednisolone retention enemas in active distal ulcerative colitis. Scand J Gastroenterol 1987;22:987-92.

5. Leijonmarck CE, Löfberg R, Öst A, Hellers G. Long-term results of ileorectal anastomosis in ulcerative colitis in Stockholm County. Dis Colon Rectum 1990;33:195-200.

6. Oakley JR, Jagelman DG, Fazio V, et al. Complications and quality of life after ileorectal anastomosis for ulcerative colitis. Am J Surg 1985;149:23-30.

7. Fleshman JW, Cohen Z, McLeod RS, Stern H, Blair J. The ileal reservoir and 
anastomosis procedure. Dis Colon Rectum 1988;31:10-6.

8. Pemberton JH, Kelly KA, Beart RW Jr, Dozois RR, Wolff BG, Ilstrup DM.

Ileal pouch-anal anastomosis for chronic ulcerative colitis. Ann Surg 1988;206:504-13.

9. Wexner SD, Wong WD, Rothenberger DA, Goldberg SM. The ileoanal reservoir. Am J Surg 1990;159:178-84.

10. Nicholls R]. Restorative proctocolectomy with various types of reservoir. World J Surg 1987;11:751-62.

11. Liljeqvist L, Lindquist K, Ljungdahl I. Alterations in ileoanal pouch technique, 1980 to 1987. Dis Colon Rectum 1988;31:929-38.

12. Wexner SD, Jensen $\mathrm{L}$, Rothenberger DA, Wong WD, Goldberg SM. Longterm functional analysis of the ileoanal reservoir. Dis Colon Rectum
1989;1932:275-81.

13. Baker WNW, Glass RE, Ritchie JK, Aylett SO. Cancer of the rectum following colectomy and ileorectal anastomosis for ulcerative colitis. Br J Surg 1978;65:862-8.

14. Johnson WR, Hughes ESR, McDermott FT, Katrivessis H. The outcome of patients with ulcerative colitis managed by subtotal colectomy. Surg Gynecol Obstet 1986;162:421-5.

15. Hawley PR. Ileorectal anastomosis. $\mathrm{Br} J$ Surg 1985;72(Suppl):75-6.

16. Oakley JR, Lavery IC, Fazio VW, Jagelman DG, Weakley FL, Easley K. The fate of the rectal stump after subtotal colectomy for ulcerative colitis. Dis Colon Rectum 1985;28:394-6.

17. Farnell MB, van Heerden JA, Beart RW Jr, Weiland LH. Rectal preservation in nonspecific inflammatory dis- ease of the colon. Ann Surg 1980;192:249-53.

18. Löfberg R, Tribukait B, Öst A, Broström O, Reichard H. Flow cytometric DNA analysis in longstand. ing ulcerative colitis: A method of prediction of dysplasia and carcinoma development? Gut 1987;28:1100-6.

19. Löfberg R, Broström O, Karlen P, Tribukait B, Öst $\AA$. Colonoscopic surveillance in longstanding total ulcerative colitis - A fifteen year follow-up study. Gastroenterology. (In press)

20. Heald RJ, Allen DR. Stapled ileo-anal anastomosis: A technique to avoid mucosal proctectomy in the ileal pouch operation. Br J Surg 1986;73:571-2.

21. Oresland T, Fasth S, Nordgren S, Hulten L. The clinical and functional outcome after restorative proctocolectomy. Int J Color Dis 1989;4:50-6. 


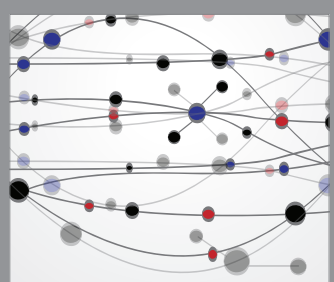

The Scientific World Journal
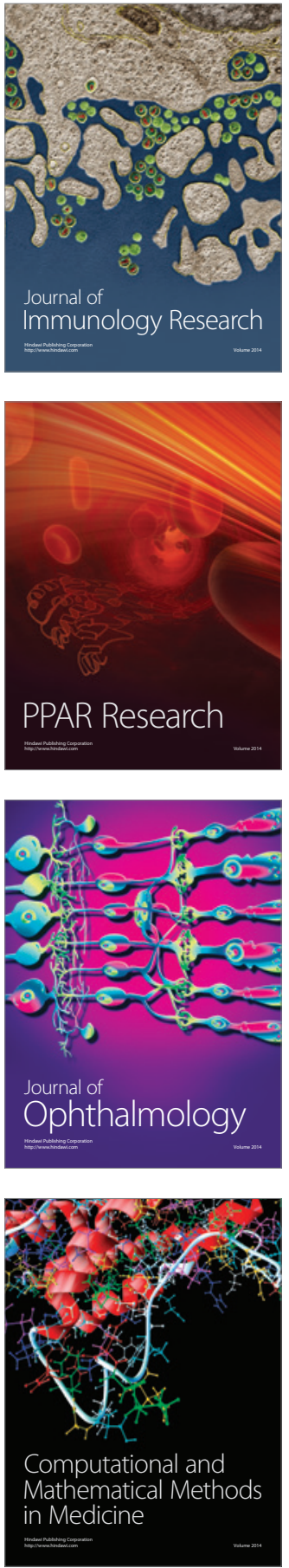

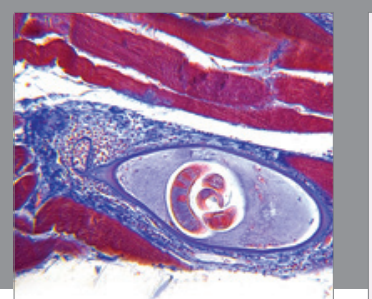

Gastroenterology Research and Practice

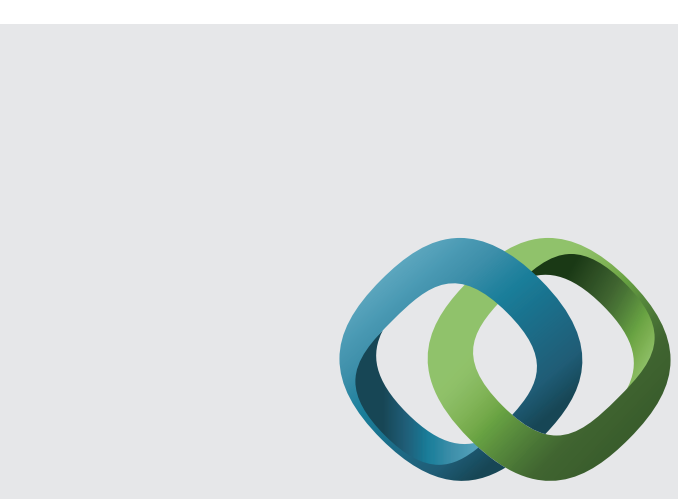

\section{Hindawi}

Submit your manuscripts at

http://www.hindawi.com
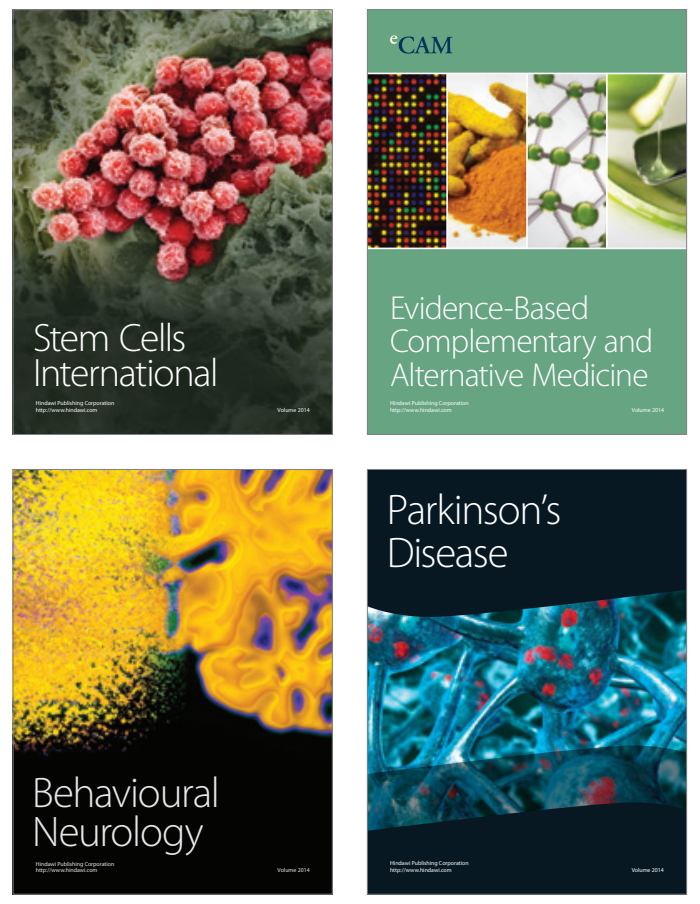
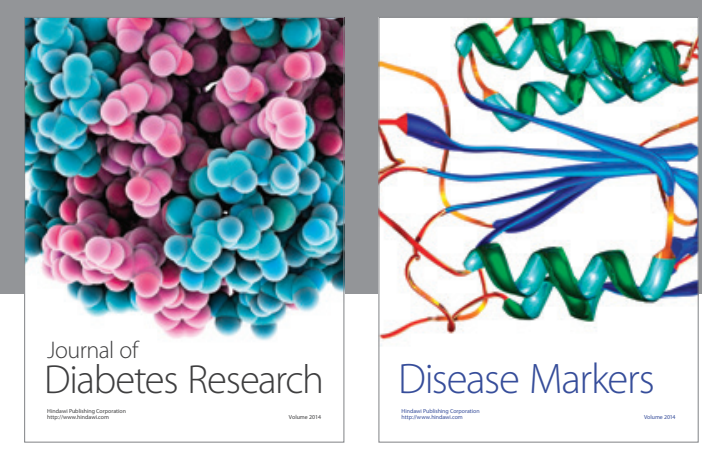

Disease Markers
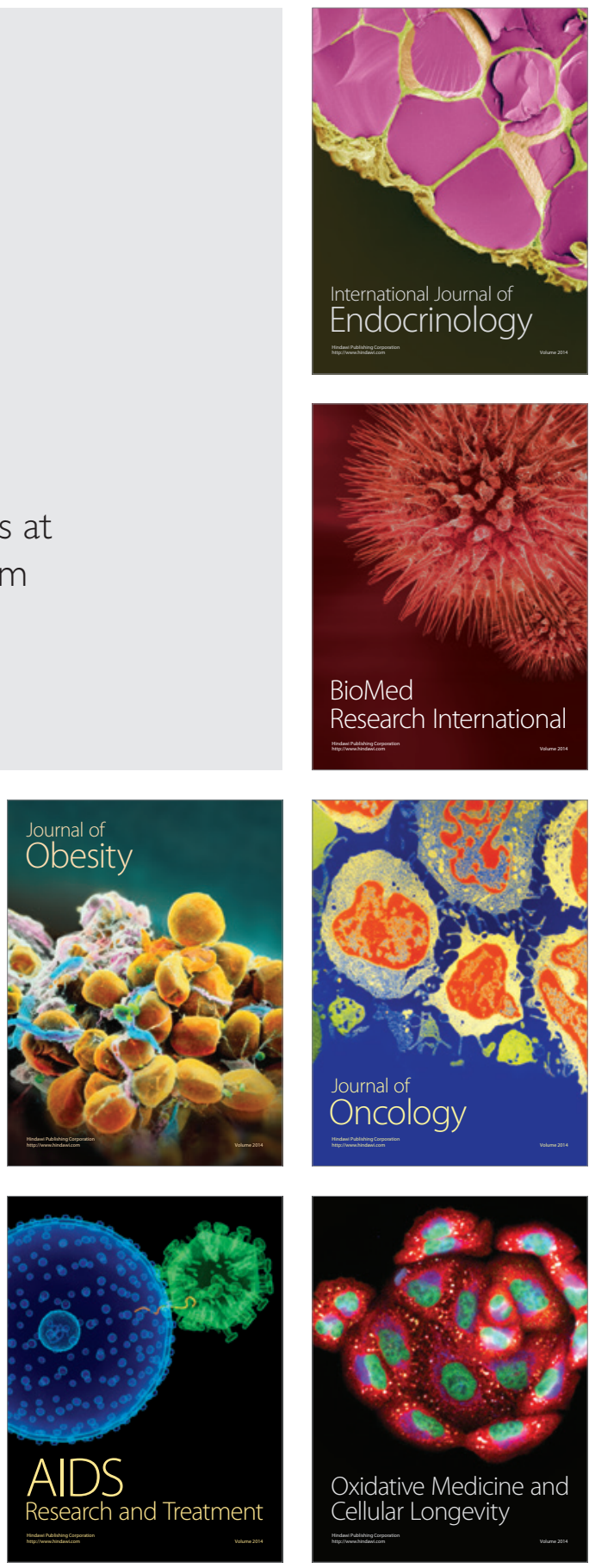